\title{
Evaluation of a Subsurface Oxygenation Technique Using Colloidal Gas Aphron Injections Into Packed Column Reactors
}

\section{Topical Report}

\section{R.A. Wills \\ P. Coles}

November 1991

Work Performed Under Contract No.: DE-FC21-86MC11076

For

U.S. Department of Energy

Office of Fossil Energy

Morgantown Energy Technology Center

Morgantown, West Virginia

By

University of Wyoming

Western Research Institute

Laramie, Wyoming 


\section{DISCLAIMER}

This report was prepared as an account of work sponsored by an agency of the United States Government. Neither the United States Government nor any agency thereof, nor any of their employees makes any warranty, express or implied, or assumes any legal liability or responsibility for the accuracy, completeness or usefulness of any information, apparatus, product, or process disclosed, or represents that its use would not infringe privately owned rights. Reference herein to any specific commercial product, process, or service by trade name, trademark, manufacturer, or otherwise, does not necessarily constitute or imply its endorsement, recommendation, or favoring by the United States Government or any agency thereof. The views and opinions of authors expressed herein do not necessarily state or reflect those of the United States Government or any agency thereof.

This report has been reproduced directly from the best available copy.

Available to DOE and DOE contractors from the Office of Scientific and Technical Information, P.O. Box 62, Oak Ridge, TN 37831; prices available from (615)576-8401, FTS 626-8401.

Available to the public from the National Technical Information Service, U.S. Department of Commerce, 5285 Port Royal Rd., Springfield, VA 22161. 
Evaluation of a Subsurface Oxygenation Technique Using Colloidal Gas Aphron Injections Into Packed Column Reactors

Topical Report

R.A. Wills

P. Coles

Work Performed Under Contract No.: DE-FC21-86MC11076

For

U.S. Department of Energy

Office of Fossil Energy

Morgantown Energy Technology Center

P.O. Box 880

Morgantown, West Virginia 26507-0880

\author{
By \\ University of Wyoming \\ Western Research Institute \\ P.O. Box 3395 \\ University Station \\ Laramie, Wyoming 82071
}

November 1991 
LIST OF TABLES AND FIGURES ....................... iii

SUMMARY $\ldots \ldots \ldots \ldots \ldots \ldots \ldots \ldots \ldots \ldots \ldots \ldots \ldots \ldots \ldots \ldots \ldots \ldots \ldots \ldots \ldots$

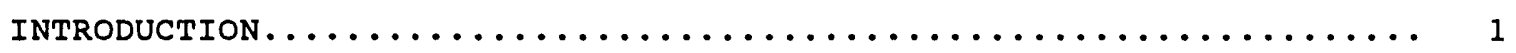

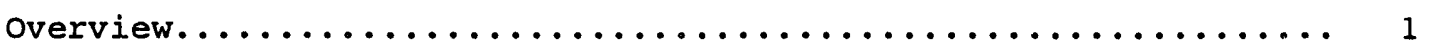

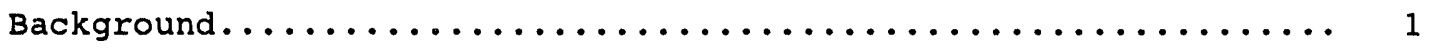

Underground Coal Gasification Site and Contamination...... 1

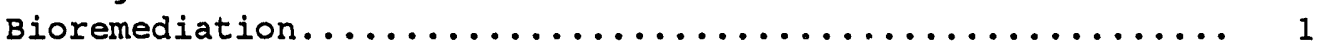

Colloidal Gas Aphrons.......................... 2

spinning-Disc Generator........................ 2

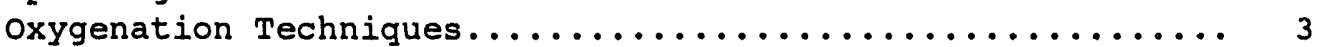

surfactant scrubbing of soils.................... 3

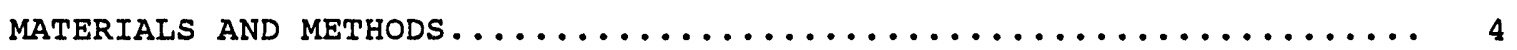

Bacteria................................. 4

Bioreactors................................... 4

Bioaugmentation............................... 4

spinning-Disc Generator........................... 4

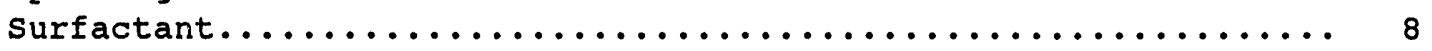

Colloidal Gas Aphrons.............................. 8

Hydrogen Peroxide............................... 8

Packed Column Reactors.............................. 9

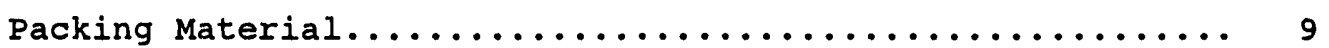

Column Design and Packing Technique................. 9

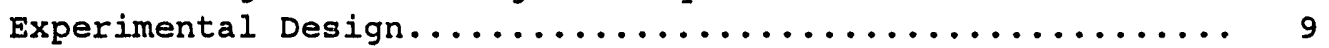

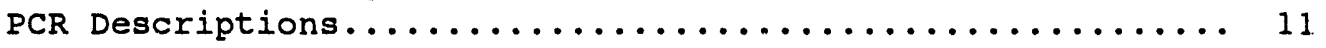

Measurement of Dissolved oxygen...................... 12

Quality Assurance and Quality Control.................... 12

RESULTS AND DISCUSSION............................... 13

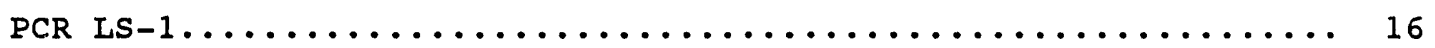

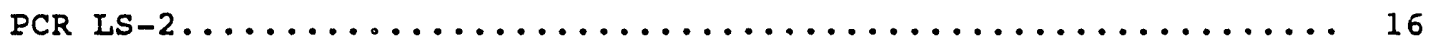

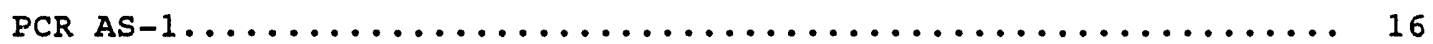

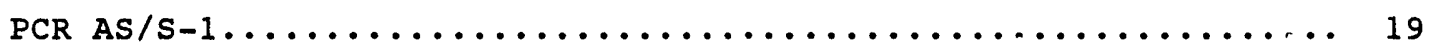

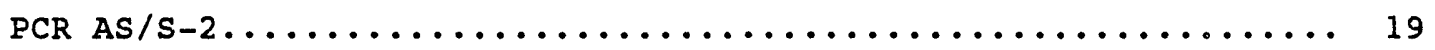

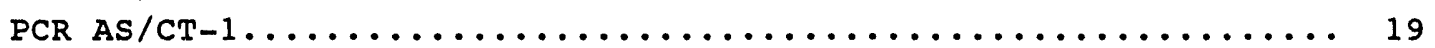

ConcLusions...................................... 22

RECOMMENDATIONS..................................... 22

ACKNOWLEDGEMENT ................................... 24

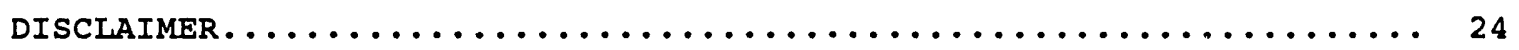

REFERENCES......................................... 25 
1. PCR Identification and Characteristics................ 10

2. Culture Development of Hoe Creek Bacteria............... 13

3. Bioreactor Data.............................. 14

4. summary of PCR Results.......................... 15

\section{IIST OF FIGURES}

\section{Figure}

$\underline{\text { Page }}$

1. Bacterial Enumeration Technique..................... 5

2. Bacterial Culture Development and Identification Procedure... 6

3. Schematic Diagram of Spinning-Disc Generator (Longe 1989).... 7

4. PCR LS-1 Dissolved Oxygen Concentration Versus Time........17

5. PCR AS-1 Dissolved Oxygen Concentration Versus Time........ 18

6. Chromatograms of: (a) Tergitol and (b) UCG Coal Tar....... 20

7. Chromatograms of PCR AS/CT-1 Effluent: (a) Before CGA Injection and (b) After CGA Injection................. 21 


\section{SUMMARY}

Bioremediation may be a remedial technology capable of decontaminating subsurface environments. The objective of this research was to evaluate the use of colloidal gas aphron (CGA) injection, which is the injection of micrometer-size air bubbles in an aqueous surfactant solution, as a subsurface oxygenation technique to create optimal growth conditions for aerobic bacteria. Along with this, the capability of CGAs to act as a soil-washing agent and free organic components from a coal tar-contaminated matrix was examined.

Injection of CGAs may be useful for remediation of underground coal gasification (UCG) sites. Because of this, bacteria and solid material from a UCG site located in northeastern Wyoming were used in this research. Colloidal gas aphrons were generated and pumped through packed column reactors (PCRs) containing post-burn core materials. For comparison, PCRs containing sand were also studied. Bacteria from this site were tested for their capability to degrade phenol, a major contaminant at the UCG site, and were also used to bioaugment the PCR systems. In this study we examined: (1) the effect of CGA injection on dissolved oxygen concentrations in the PCR effluents, (2) the effect of CGA, $\mathrm{H}_{2} \mathrm{O}_{2}$, and phenol injections on bacterial populations, (3) the stability and transport of CGAs over distance, and (4) CGA injection versus $\mathrm{H}_{2} \mathrm{O}_{2}$ injection as an oxygenation technique.

Each PCR demonstrated fluctuating bacterial populations in the effluent during establishment of baseline data. As a result, no conclusions on the increase or decrease in bacterial populations due to variables such as $\mathrm{CGA}, \mathrm{H}_{2} \mathrm{O}_{2}$, and phenol injections or bioaugmentations could be drawn. A possible reason for the fluctuations is sloughing of bacteria from the PCR material and/or the tubing used in the pumping system.

In some of the PCR experiments, an interference prevented measurement of the dissolved oxygen concentrations using a dissolved oxygen probe. Although aeration in the PCR was visible, no dissolved oxygen was detected. The interference may have been due to matrix effects on the dispersion of dissolved oxygen through the membrane of the dissolved oxygen probe.

In the two PCR systems where the measurement of dissolved oxygen was not affected by interference, increases in dissolved oxygen concentrations in the PCR effluents were observed following CGA injections. Data from this research also show that CGA solutions having lower surfactant concentrations contained higher dissolved oxygen concentrations. The CGAs used in this research also exhibited soilwashing capabilities by removing organic compounds from the coal tarcontaminated matrix. Decreases in dissolved oxygen concentrations in PCR effluents following bioaugmentation were observed.

The interference that prohibited measurement of dissolved oxygen greatly reduced the amount of data available upon which conclusions can be based; however, the limited data suggest that oxygen generation through CGA injection is a viable subsurface oxygenation technique. 
This, along with the determination that the bacteria isolated from the UCG site can degrade phenol, suggests that enhanced bioremediation of subsurface environments is feasible.

Problems associated with studying this in situ technology (such as the unpredictable fluctuations in bacterial populations and the analytical difficulties) must be addressed. In addition, much more information concerning the many mechanisms interacting simultaneously in this in situ technology is needed.

It can also be concluded that CGAs act as a soil-washing agent. This may be of significance for freeing organic matter and making it more accessible to the bacteria for degradation; it also shows a possible separate application of CGAs as a soil-washing agent. 
INTRODUCTION

\section{Overview}

We evaluated the use of colloidal gas aphron (CGA) injection as a subsurface oxygenation technique. This is an engineering teclinology that may be used to modify subsurface environments and create optimal growth conditions for aerobic bacteria. This subsurface oxygenation technique may be used to biostimulate underground coal gasification (UCG) sites where biological processes may be the only technology capable of remediating the subsurface environment.

The use of CGAs as a soil-washing agent was also evaluated. The surfactant used to generate CGAs may emulsify contaminants associated with matrix materials. This may be of significance for freeing the organic matter and making it more accessible to the bacteria for degradation, as well as for using CGAs as a soil-washing agent.

\section{Background}

\section{Underground Coal Gasification site and Contamination}

Lawrence Livermore National Laboratories conducted three separate UCG experiments at the Hoe creek site in northeastern Wyoming. UCG experiments were carried out to determine if the process could deliver synthetic fuels to the surface and eliminate mining of the coal. The process was successful in retrieving synthetic fuels; however, the experiments were conducted using excessive pressure that caused residual gasification products to be pushed into the formation. This contamination was subsequently introduced into the groundwater system. Contamination from organic compounds resulted from pyrolytic reactions, and inorganic contamination occurred through coal ash leaching (Mead et al. 1980; Wang and Mead 1985). Even after several years, stuermer et al. (1982) identified 135 organic compounds in the groundwater, including phenols, aromatic carboxylic acids, aromatic hydrocarbons, ketones, aldehydes, pyridines, and aromatic amines.

The residual contaminants produced by UCG can be divided into two groups: the inorganic constituents of the coal ash and the organic species that are produced during the pyrolysis phase of gasification. Unlike the inorganic components, the organic materials are volatile and easily transported from the burn zone into the surrounding coal seam. Phenolic materials are major organic water-soluble contaminants that result from gasification (Dalton and Campbell 1978). In UCG processes, organic compounds, such as sparingly soluble tars, may be produced or deposited in a form that resists dissolution, creating a long-lived contaminant source.

\section{Bioremediation}

The term bioremediation defines the removal or alteration of chemical species in the environment by microorganisms that are capable of degrading chemicals through biotransformations or biochemical ronversions. Many studies have been conducted to examine the influence 
of physical, chemical, and biological factors on the microbial degradation of individual chemical pollutants (Horvath 1972; Kim and Maier 1987; Hwang et al. 1989). Adams (1986) isolated bacteria from Hoe Creek wastewaters and demonstrated their ability to degrade phenol. Nolan and Suthersan (1987) evaluated biodegradation technologies for the Hoe creek site.

on-site bioremediation systems involving soil make use of the naturally occurring (i.e., indigenous) microorganisms or introduce (i.e., bioaugment) microorganisms to treat the contaminants. Sites may not possess indigenous bacteria that are capable of degrading contaminants. As a result, bioaugmentation may be necessary for bioremediation.

\section{Colloilal Gas Aphrons}

Colloidal gas aphrons (CGAs) are produced by a spinning-disc generator using surfactants in an aqueous solution. The CGAs are spherical, micrometer-size gas bubbles dispersed in an aqueous surfactant solution. Diameters range from $10-100 \mu \mathrm{m}$ with a volumetric gas content of 748 . CGAs are a wet foam that can be considered a microgas emulsion that has an inner gas phase and outer surfactant phase. The emulsion is a multicomponent system with at least one component in the gas phase and two components (water and surfactant) in the liquid phase.

The surfactant surrounding the gas has an ordered structure and is thicker than ordinary soap bubbles. The small size and the physical positioning of surfactant molecules enhance their stability. The physical position of surfactant molecules at the interface leads to repulsive, electrostatic forces that prevent the infinite thinning of the encapsulating shell. The stability of the interface is enhanced by the water-soluble nature of the surfactant, which creates an electrically diffuse double layer of ionized molecules and increases hydrogen bonding (Smith 1988; Longe 1989).

There are many potential applications for CGAs in treating polluted soil and water. Researchers, Smith (1988), Michelsen et al. (1988 $a, b, c)$, and Michelsen et al. (1985), report that CGAs can be used to deliver oxygen that may enhance biological degradation in saturated soil systems. There are several models that describe the possible transport of CGAs through porous media (Longe 1989). Once the CGAs have been transported, the oxygen is released and is carried with the groundwater to the bacteria that adhere to the soil and to the bacteria that are free-floating in solution.

\section{Spinning-Disc Generator}

The spinning-disc generator (developed by sebba 1985) is a mechanical gas-liquid contactor that creates surface waves to introduce gas into the liquid phase (surfactant in water). The gas is subsequently broken into small bubbles and entrained. 
Three components are required in a spinning-disc generator: a shearing device, baffles, and a holding vessel. The size and positioning of these components are crucial to the generation of CGAs with a consistent size and nature. The shearing device is a form of disc-type radial-flow impeller. Baffles are necessary to direct flow from the disc. This produces the required vertical currents and ensures that the entire fluid passes through the disc zone where maximum shearing effects occur.

\section{Oxygenation Techniques}

Subsurface oxygenation techniques currently exist, but have some problems associated with them. The most widely used methods for oxygenating subsurface environments include injections of hydrogen peroxide $\left(\mathrm{H}_{2} \mathrm{O}_{2}\right)$ solutions and injections of air (air sparging). The use of air sparging is limited because the movement of oxygen in formations is inconsistent. Air sparging can be used only in highly permeable formations (Smith 1988). Foss (1989) compared CGA injection and airsparging oxyonsation techniques. Their study showed that CGAs had a much greater retention of air in soil.

Hydrogen peroxide is more efficient than air sparging by several orders of magnitude. Field tests show that $\mathrm{H}_{2} \mathrm{O}_{2}$ will increase the dissolved oxygen concentrations in formations, whereas air sparging left them oxygen deficient. However, the utility of $\mathrm{H}_{2} \mathrm{O}_{2}$ is limited by three factors. First, $\mathrm{H}_{2} \mathrm{O}_{2}$ is cytotoxic above certain concentrations and will kill microorganisms. A second limitation is that $\mathrm{H}_{2} \mathrm{O}_{2}$ is very reactive, and it rapidly decomposes. Rapid decomposition limits its transportability. A third limitation is the expense of using $\mathrm{H}_{2} \mathrm{O}_{2}$. Large quantities of $\mathrm{H}_{2} \mathrm{O}_{2}$ may be required to achieve the desired oxygen concentration.

Colloidal gas aphrons exhibit flow-smoothing properties in porous media, which prevents fingering and creates even distributions of oxygen. Colloidal gas aphrons may also emulsify contaminants and provide nutrients for the bacteria (Longe 1989; Smith 1988). Colloidal gas aphrons exhibit viscosity and rheological properties that are similar to water. This allows them to be transported via pumping. Therefore, the CGA injection may be more effective than air sparging or hydrogen peroxide injection because CGAs should be more stable and have process-enhancing effects.

\section{Surfactant scrubbing of soils}

The surfactant required in the generation of CGAs also acts as a soil-scrubbing agent. Rickabaugh et al. (1987) demonstrated that surfactanc solutions were more efficient than water in removing chlorinated hydrocarbons from scils. Up to 598 of 11 target compounds was removed in one week of soil scrubbing with surfactant solutions, whereas scrubbing with water removed lesis than 18. 


\section{MATERIALS AND METHODS}

\section{Bacteria}

Bacteria were isolated from Hoe Creek water samples taken from monitoring wells DOE-10, WS-21, and CRS-1 during the May 1990 sampling trip. These bacteria were enumerated in the original samples and then cultured using phenol as the sole carbon source available for metabolization. Increasing concentrations of phenol, 100, 200, and 400 $\mathrm{mg} / \mathrm{L}$, were successively added to the cultures, and bacteria were enumerated to determine growth in each concentration. The bacteria from the $400 \mathrm{mg} / \mathrm{L}$ phenol solution were then cultured in contained bioreactors to study the degradative capabilities of the cultures and determine growth versus phenol degradation rates.

\section{Bioreactors}

The bioreactors used in this research consisted of flasks that were sealed with rubber stoppers and parafilm. The stopper housed two glass rods that were positioned above the solution in the flask. The inlet rod was sealed with a rubber septum to allow for air injection, and the outlet rod was connected to an open/close valve. The bioreactors were incubated at $35^{\circ} \mathrm{C}$ for two weeks in a shaking water bath. Air was injected into the bioreactors twice during this period to prevent anaerobic conditions. At the end of the incubation period, the aqueous solutions were analyzed for phenol concentrations using U.S. Environmental Protection Agency (EPA) Method 604 (U.S. EPA 1984a), and bacterial populations were enumerated using the standard Heterotrophic Spread Plate Count Method 907-B (Standard Methods for the Examination of Water and Waste water 1985). Figure 1 shows the technique used to enumerate the bacteria.

\section{Bioaugmentation}

Cultures of proven phenol degraders were used to bioaugment the indigenous bacteria in the matrix material used in this research. Figure 2 shows the bacterial culture development and identification procedures followed in preparation for bioaugmentation. The bacteria listed in Figure 2 were identified by Microbial Identification, Inc. using fatty acid content determined by gas chromatography (GC).

\section{Spinning-Disc Generator}

The CGAs used in this research were generated using a spinning-disc generator and the surfactant Tergitol ${ }^{\mathrm{TM}}$. The spinning-disc generator was assembled according to the design specifications of Longe (1989) and smith (1988) (Figure 3). The equipment required for a spinning-disc generator consists of a $6.20-\mathrm{cm}$-diameter, $0.16-\mathrm{cm}$-thick, stainless steel disc mounted horizontally on the end of a vertical shaft. The shaft is connected to a $0.083-\mathrm{hp}$ electric motor equipped with a variable speed controller. Two plexiglass baffles measuring $3.81 \times 20.3 \mathrm{~cm}$ and $0.64 \mathrm{~cm}$ thick are attached to a support so that they lie in the same vertical plane and are an equal distance from the shaft. The baffles are shaped to encompass the spinning disc and are positioned $1.9 \mathrm{~cm}$ from the vessel 


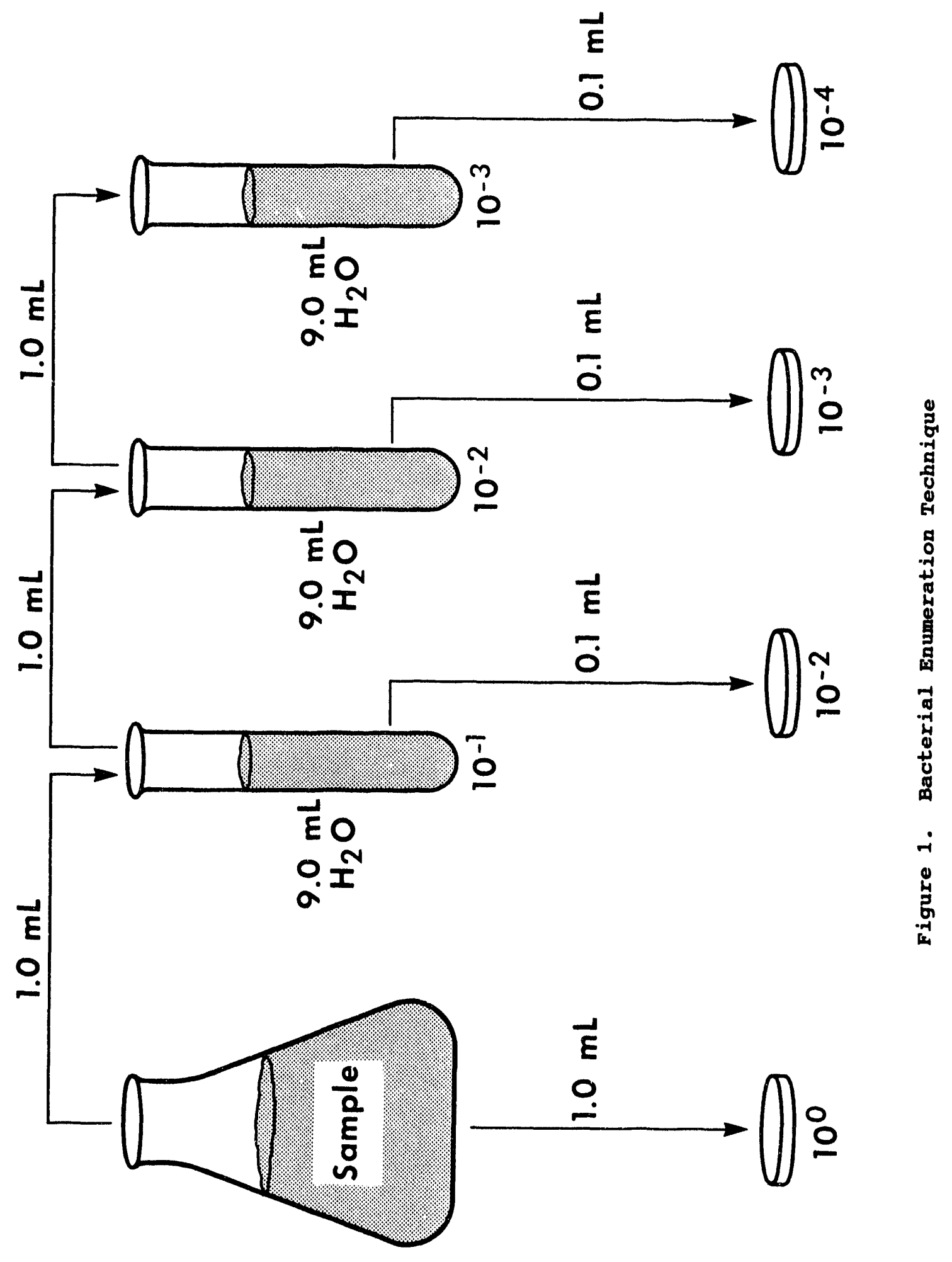




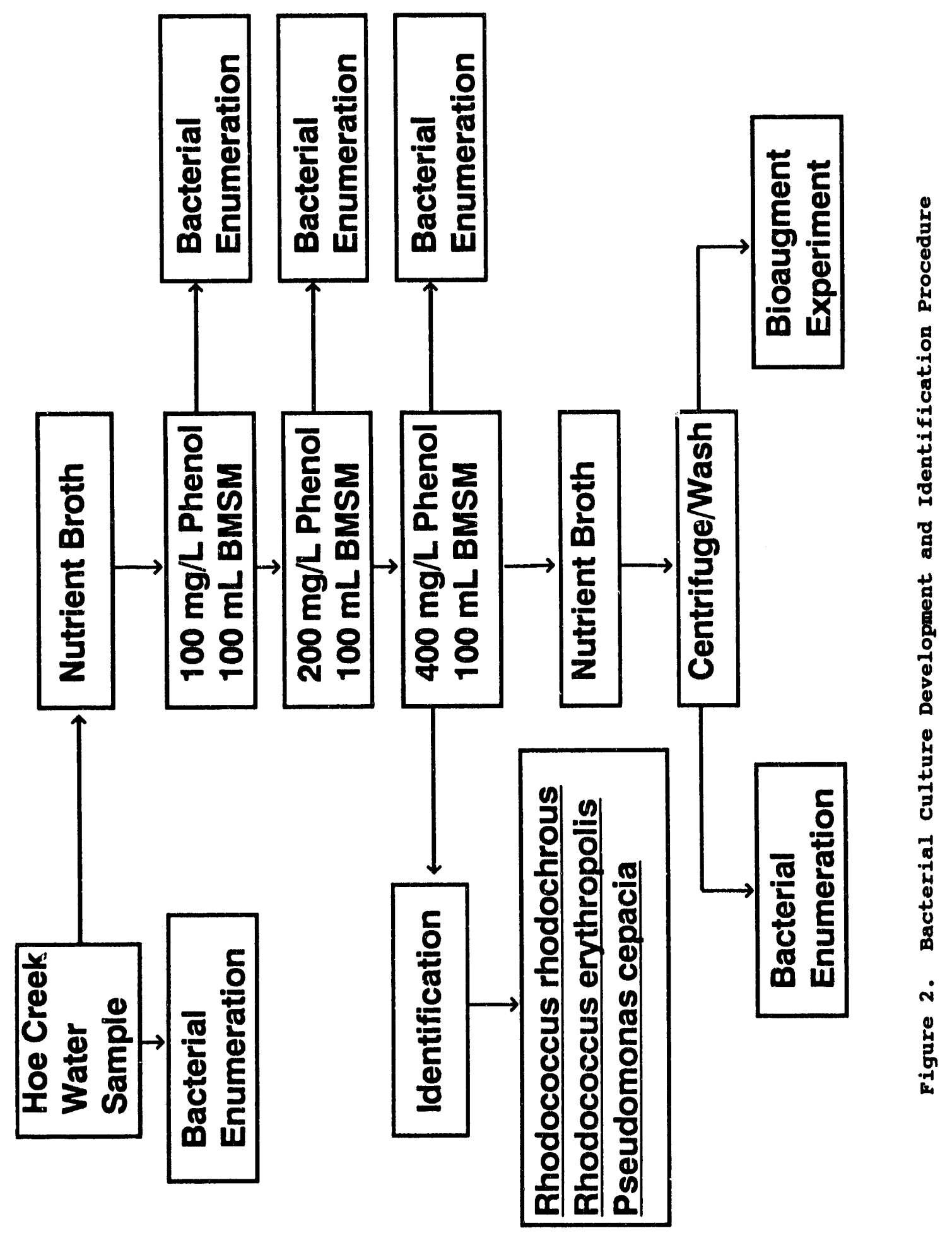




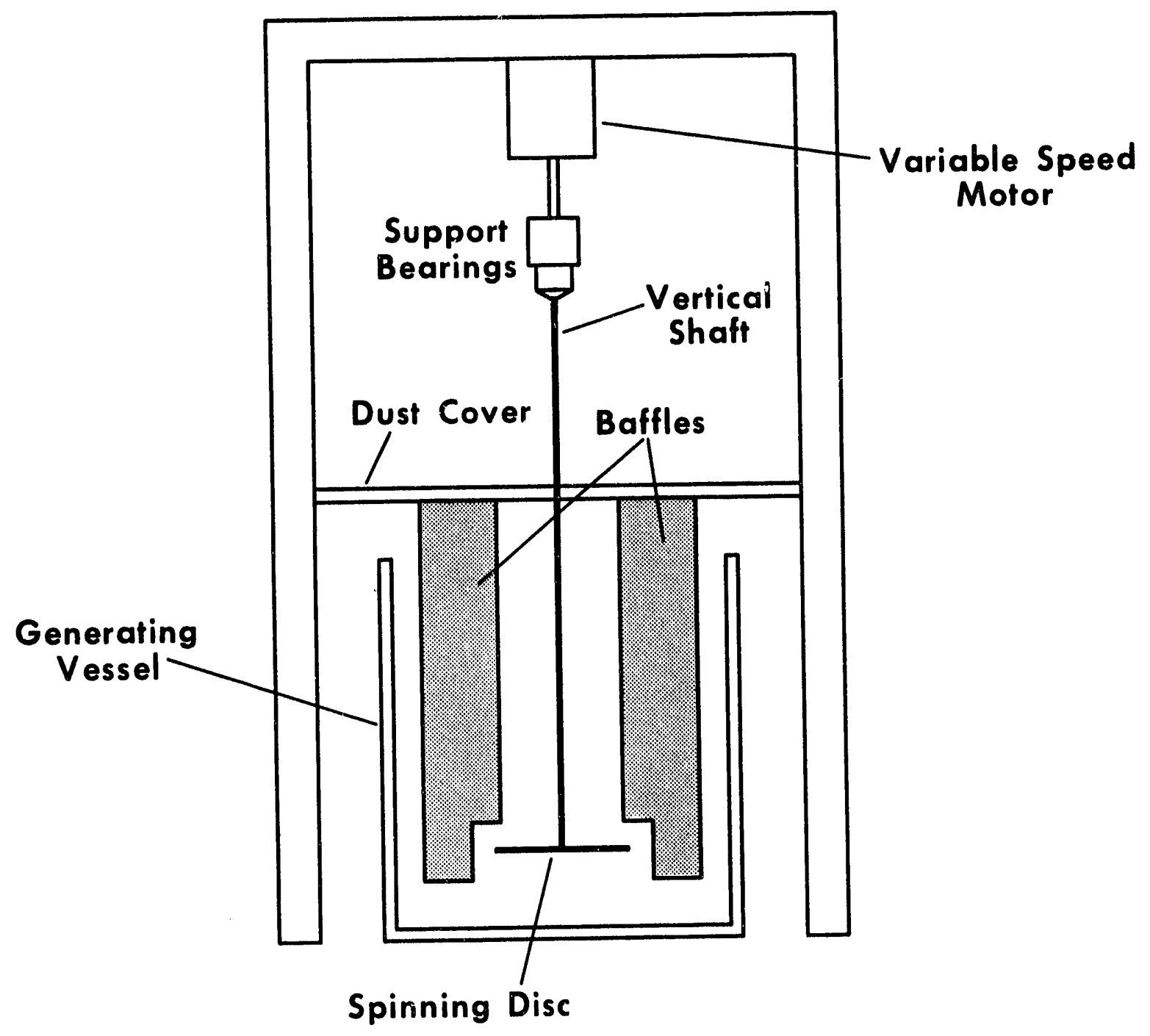

Figure 3. Schematic Diagram of Spinning-Disc Generator (Longe 1989) 
walls and $2.5 \mathrm{~cm}$ from the bottom of the container. A 4-L stainless steel vat serves as the holding vessel. A port is located on the side of the holding vessel to allow withdrawal of the CGAs. Peristaltic pumps are used to transport the CGAs.

\section{Surfactant}

Alkyloxypolyethylenoxyethanol, $\mathrm{C}_{12} \mathrm{H}_{25}\left(\mathrm{CH}_{2} \mathrm{CH}_{2} \mathrm{O}\right) \mathrm{CH}_{2} \mathrm{CH}_{2} \mathrm{OH}$, commonly named Tergitol 15-S-12, was the nonionic, biodegradable surfactant used to produce CGAs. Tergitol was analyzed to determine characteristics that might afiect the results of our experiments. GC analysis of Tergitol showed the absence of phenol. GC analysis was performed using EPA Method 604 on a Hewlett-Packard 5890 series II gas chromatograph with a flame ionization detector (FID). GC/mass spectrometry (MS) analyses of Tergitol using EPA Method 625 (U.S. EPA $1984 \mathrm{~b}$ ) also demonstrated the absence of phenol. GC/MS analysis was performed on a Hewlett-Packard MSD Model 5970.

Jergitol was analyzed for the presence of bacteria and determined to be sterile. A dilution of the surfactant was inoculated with bacteria. After a one-week incubation period, bacterial enumeration showed that the bacteria were maintaining on the surfactant but not flourishing on it.

\section{Colloidal Gas Aphrons}

The diameter of CGAs, prepared using the spinning-disc generator and the surfactant, Tergitol, described above, is expected to be less than $100 \mu \mathrm{m}$ (Longe 1989; Smith 1988). Various concentrations of Tergitol in water were tested in generating CGA solutions to determine those that produced the highest dissolved oxygen content. The CGA solutions that we examined had surfactant concentrations of $1,50,60$, and $100 \mathrm{~mL} / \mathrm{L}$. once CGAs were generated, the holding vessel was submerged in an ice bath to reduce the coalescence rate. The solutions were cooled to $11^{\circ} \mathrm{C}$ in the ice bath to prevent the CGAs from bursting prematurely.

The dissolved oxygen content of the CGA solutions was measured using a YSI 5739 probe connected to a Model 58 oxygen meter. The dissolved oxygen concentration of the Milli- $Q^{\text {TM }}$ water used in our research was 4.5 $\mathrm{mg} / \mathrm{L}$ at $11^{\circ} \mathrm{C}$. In the process of generating the CGA solutions, Milli-Q water is whipped, and the dissolved oxygen concentration of whipped water at $11^{\circ} \mathrm{C}$ is $5.7 \mathrm{mg} / \mathrm{L}$. The dissolved oxygen concentrations of the CGA solutions having surfactant concentrations of $1 \mathrm{~mL} / \mathrm{L}, 50 \mathrm{~mL} / \mathrm{L}, 60$ $\mathrm{mL} / \mathrm{L}$, and $100 \mathrm{~mL} / \mathrm{L}$ at $11^{\circ} \mathrm{C}$ are $8.0,7.9,7.9$, and $7.2 \mathrm{mg} / \mathrm{L}$, respectively.

\section{Hydrogen Peroxide}

A concentration of $100 \mathrm{mg} / \mathrm{L}$ of $\mathrm{H}_{2} \mathrm{O}_{2}$ in Milli-Q water was used for the $\mathrm{H}_{2} \mathrm{O}_{2}$ injections. The dissolved oxygen concentration of this solution at $11^{\circ} \mathrm{C}$ is $7.0 \mathrm{mg} / \mathrm{L}$. 


\section{Packed Column Reactors}

\section{Packing Material}

Four packed column reactors (PCRs) were packed with core material obtained from the postburn coring activity at the Hoe creek UCG site. These cores had been sealed in a wax coating for approximately 12 years before we obtained them for use as PCR matrix material in our column studies. The cores consisted of altered sand; altered sand was the term used by Ethridge et al. (1979) for the sedimentary strata in and directly above the burn cavity. The mineral and textural changes caused by the burn altered the sand and formed pyrometamorphic material. The altered sand may have been further changed by the introduction of contamination from the pyrolysis of coal and the leaching of coal ash (Ethridge et al. 1979). The core material was ground and sieved prior to being packed into the PCRs. Some of the core material (altered sand) used in the PCRs contained slag.

Two PCRs were packed with a local sand that was collected at the same location near Laramie, wyoming but at different times. The sand was sieved prior to being added to the PCRs.

The percentage of grain sizes was determined and the surface area was calculated for the material used in each PCR (Table 1). The particle size of the material packed into the PCRs ranged between sand and a silty sand. In this report we will use the term PCR material to describe the solid used to pack the column apparatus.

\section{Column Design and Packing Technique}

Glass wool, a stainless steel screen, and a perforated Teflon ${ }^{\mathrm{TM}}$ disc were placed into the bottom of each PCR to hold the contents in position. A Panosonic Panabrator XII vibrator was used to vibrate the PCR material into the column. A known weight of material was gradually added while the PCR was kept vibrating. This vibration produced consistent packing of the PCR material into the column. In one PCR containing core material, we added a layer of UCG coal tar mixed with core material near the top of the PCR.

Glass wool, a stainless steel screen, and a perforated Teflon disc were placed at the top of each PCR to hold the packed material in place. The perforated discs also served as a dispersion disc for incoming solutions. Caps housing the valves and pressure gauges for incoming and outflowing solutions were held in place with clamps on the bottom and top of the PCRs.

\section{Experimental Design}

After the PCRs were packed, the pore volume was determined by measuring the amount of water required to saturate the PCR material. PCR identification, length, pore volume, porosity, permeability, and hydraulic conductivity are listed in Table 1. Permeability was calculated using Darcy's equation, and was then converted to hydraulic conductivity using the conversion table in Freeze and cherry (1979). 


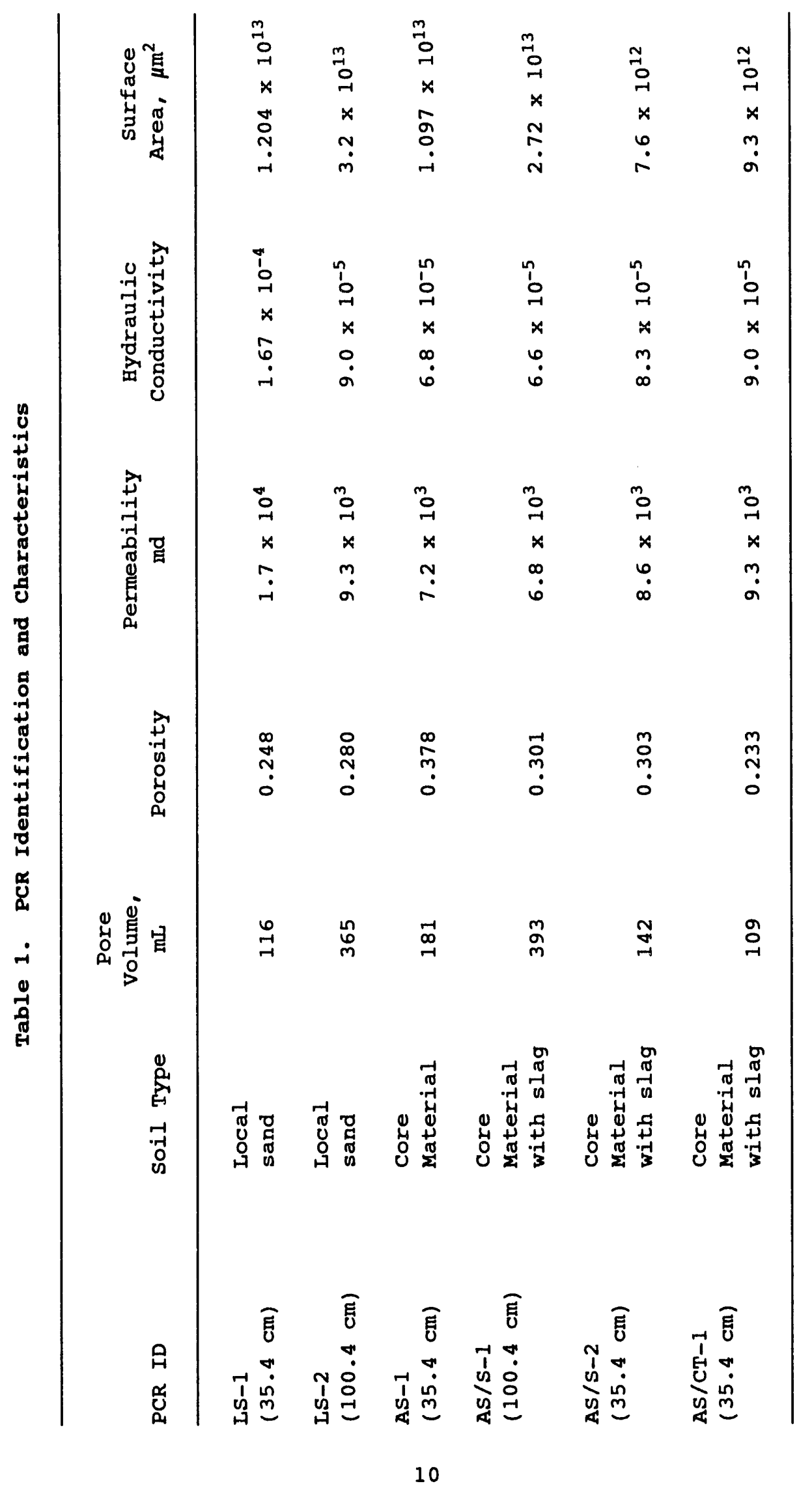


Pressure gradients were measured using pressure gauges located at the top and bottom of each PCR.

To simulate groundwater flow, Milli-Q water was pumped continuously through PCRs using positive displacement (Model QG6/HOCKC) pumps from Fluid Metering, Inc. The Milli-Q water was contained in a glass carboy. Tygon TM tubing connected the carboy to a pump and then to the PCR. The Milli-g water was pumped through a $0.2-\mu \mathrm{m}$ filter before entering the PCR.

The simulated groundwater flow in all of the PCRs was approximately $10 \mathrm{~mL} / \mathrm{hr}$. In these experiments, we did not attempt to simulate the hydraulic conductivity at the Hoe creek site. Baseline data were obtained by pumping Milli-Q water through the PCR and monitoring the effluent.

Once baseline data were established, $\mathrm{CGA}, \mathrm{H}_{2} \mathrm{O}_{2}$, and phenol solutions were pumped through the PCRs using peristaltic pumps. Phenol solutions were contained in a glass carboy. Tygon tubing connected the carboy to a pump and the pump to each PCR. Phenol solutions were pumped through a $0.2-\mu \mathrm{m}$ filter before entering the PCR. Bacterial, CGA, and $\mathrm{H}_{2} \mathrm{O}_{2}$ solutions were not filtered.

The PCR effluent passed through a flow-through cell containing a dissolved oxygen probe. The effluent was then collected in a flask and analyzed. Phenol was extracted from the effluent for analysis by EPA Method 604 using a Hewlett-Packard 5890 series II gas chromatograph with an FID. Bacterial enumerations of the PCR effluents were performed using the standard Heterotrophic spread Plate Count Method 907-B.

\section{PCR Descriptions}

PCR LS-1 was packed with local sand. This 35.4-cm long PCR was positioned horizontally and was used to test packing techniques, flow rates, pumping systems, sample collection, and analytical procedures. In addition, this PCR was designed to provide information on the effect of CGA injections, containing $1.0 \mathrm{~mL}$ of surfactant per $1.0 \mathrm{I}$ of water, on the dissolved oxygen concentrations in the PCR effluent. An injection of a 100-ppm phenol solution was pumped through PCR LS-1 to study the effects of phenol on the bacterial populations. A bioaugmentation was also injected into this PCR.

PCR IS-2 was also packed with local sand. This 100.4-cm long PCR was positioned horizontally. PCR LS-2 was 2.8 times longer than PCR LS1 and was designed so that the stability of the CGAs over distance could be compared. Both $100-\mathrm{ppm} \mathrm{H}_{2} \mathrm{O}_{2}$ solutions and $\mathrm{CGA}$ injections, containing various surfactant concentrations, were pumped into this PCR to compare oxygenation techniçues.

PCR AS-1 was packed with core material. This 35.4-cm long PCR was positioned horizontally and was designed to study the effect of CGA injections, containing surfactant concentrations of 50 and $100 \mathrm{~mL} / \mathrm{L}$, on the dissolved oxygen concentrations in the PCR effluent. A 100-ppm phenol solution was pumped intermittently through this PCR. A bioaugmentation was also injected into this PCR. 
PCR AS/S-1 was packed with core material that contained slag. This $100.4-\mathrm{cm}$ long PCR was positioned vertically to evaluate the vertical mobility of CGAs. CGA injections, containing various surfactant ratios, and injections of $100-\mathrm{ppm} \mathrm{H}_{2} \mathrm{O}_{2}$ solutions were performed.

PCR AS/S-2, positioned horizontally, was packed with core material containing slag. Both $100-\mathrm{ppm} \mathrm{H}_{2} \mathrm{O}_{2}$ solutions and CGA injections, containing various surfactant concentrations, were pumped into this PCR to compare oxygenation techniques.

PCR AS/CT-1, positioned horizontally, was packed with core material and contained a one-inch layer of coal tar mixed with core material near the top of the PCR. CGA injections, containing various surfactant concentrations, were pumped through this PCR to study their effect on the dissolved oxygen concentrations in the PCR effluent and their soilwashing capabilities.

\section{Measurement of Dissolved Oxygen}

As mentioned earlier, the PCR effluent passed through a flowthrough cell that contained a dissolved oxygen probe. oxygen gas molecules diffuse through the membrane of the probe into a measuring cell at a rate proportional to the partial pressure of oxygen in the effluent. Inside the sensor, the oxygen reacts with an electrolyte and is reduced by an applied voltage. The current is directly proportional to the partial pressure of oxygen in the effluent outside the sensor (Freeze and cherry 1979).

\section{Quality Assuxance and Quality Control}

To ensure the quality of the data, both general quality assurance (QA) procedures presently in place at Western Research Institute and project-specific $Q A$ procedures were followed. These included standard operating procedures and special protocols.

The baseline data for each PCR served as the control blank for each experiment. All solutions that were pumped into the PCR systems were characterized before injection. Sterile conditions were maintained whenever possible with respect to the introduction of constituents into the PCRs. Bacterial culture development followed strict sterile procedures and techniques. 


\section{RESULTS AND DISCUSSION}

The bacteria, isolated from the Hoe creek UCG site, demonstrated growth in increasing concentrations of phenol over time (Table 2). The initial bacterial population in the water sample from well DOE-10 was 145.6 bacteria/mL. Following culture development, the bacterial population in the $400 \mathrm{mg} / \mathrm{L}$ phenol solution was 4,875 bacteria/mL. As mentioned earlier, bacteria from the $400 \mathrm{mg} / \mathrm{L}$ phenol solution were inoculated into bioreactors. Table 3 shows the concentration of phenol versus bacterial population in the bioreactors over time. Over a twoweek period, the initial phenol concentration decreased, while the bacterial population increased. This shows a direct relationship between bacterial growth and phenol degradation.

Table 2. Culture Development of Hoe Creek Bacteria

\begin{tabular}{|c|c|c|c|c|}
\hline Sample ID & $\begin{array}{c}\text { Serial } \\
\text { Dilutions }\end{array}$ & $\begin{array}{l}\text { Ave. No. } \\
\text { Colonies }\end{array}$ & Bacteria/mL & $\begin{array}{c}\text { Average } \\
\text { Bacteria/mL }\end{array}$ \\
\hline $\begin{array}{l}\text { Initial } \mathrm{H}_{2} \mathrm{O} \\
\text { Time } 0 \\
(\text { DOE-10) }\end{array}$ & $\begin{array}{l}10_{0} \\
10^{-1} \\
10^{-2}\end{array}$ & $\begin{array}{r}192.0 \\
14.5 \\
1.0\end{array}$ & $\begin{array}{l}192.0 \\
145.0 \\
100.0\end{array}$ & 145.6 \\
\hline $\begin{array}{l}100 \mathrm{mg} / \mathrm{L} \text { phenol } \\
\text { Time } 2 \text { weeks }\end{array}$ & $\begin{array}{l}10_{0} \\
10^{-1} \\
10^{-2}\end{array}$ & $\begin{array}{r}271.5 \\
27.0 \\
2.5\end{array}$ & $\begin{array}{l}271.5 \\
270.0 \\
250.0\end{array}$ & 263.8 \\
\hline $\begin{array}{l}200 \mathrm{mg} / \mathrm{I} \text { phenol } \\
\text { Time } 4 \text { weeks }\end{array}$ & $\begin{array}{l}10^{0} \\
10^{-1} \\
10^{-2} \\
10^{-3}\end{array}$ & $\begin{array}{r}\text { TMTC }^{\mathrm{b}} \\
30.0 \\
3.0 \\
0.5\end{array}$ & $\begin{array}{r}\text { TMTC } \\
300.0 \\
200.0 \\
500.0\end{array}$ & 333.3 \\
\hline $\begin{array}{l}400 \mathrm{mg} / \mathrm{L} \text { phenol } \\
\text { Time } 6 \text { weeks }\end{array}$ & $\begin{array}{l}10^{0} \\
10^{-1} \\
10^{-2} \\
10^{-3}\end{array}$ & $\begin{array}{r}\text { TMTC } \\
\text { TMTC } \\
47.5 \\
5.0\end{array}$ & $\begin{array}{r}\text { TMTC } \\
\text { TMTC } \\
4750.0 \\
5000.0\end{array}$ & 4875.0 \\
\hline
\end{tabular}

a Bacteria/mL = (average number bacteria $\mathrm{x}$ reciprocal dilution $\mathbf{x} 10$ : ( 10 is factor to bring bacteria count/mL rather than bacteria/0.1 $\mathrm{mL}$ (volume actually plated)

b $\quad$ TMTC $=$ Too many to count 
Table 3. Bioreactor Data

\begin{tabular}{|c|c|c|c|c|}
\hline \multirow[b]{2}{*}{ Bioreactor } & \multicolumn{2}{|c|}{ Bacteria, $\mathrm{mL}$} & \multicolumn{2}{|c|}{ Phenol, mg/L } \\
\hline & Initial & Final & Initial & Final \\
\hline Phenol 1 & $9.37 \times 10^{3}$ & $4.55 \times 10^{7}$ & 96.46 & 19.09 \\
\hline Phenol 2 & $9.37 \times 10^{3}$ & $3.45 \times 10^{7}$ & 96.46 & 13.00 \\
\hline Phenol without bacteria & 0.00 & $5.95 \times 10^{4}$ & 99.66 & 43.40 \\
\hline Bacteria without phenol & $9.39 \times 10^{3}$ & $6.07 \times 10^{4}$ & 0.00 & $<0.5^{\mathrm{a}}$ \\
\hline
\end{tabular}

a Detection limit of instrument

A summary of the results and observations for each PCR experiment is listed in Table 4. In performing the research, problems were encountered, which prevented us from obtaining data on the effects of CGA, $\mathrm{H}_{2} \mathrm{O}_{2}$, and phenol injections on bacterial growth, and in some cases, prevented us from measuring dissolved oxygen concentrations after CGA and $\mathrm{H}_{2} \mathrm{O}_{2}$ injections.

Each PCR demonstrated unpredictable fluctuating bacterial populations in the effluent during establishment of baseline data. As a result, no conclusions on the increase or decrease in bacterial populations due to variables such as $\mathrm{CGA}, \mathrm{H}_{2} \mathrm{O}_{2}$, and phenol injections or bioaugmentations could be drawn. Possible reasons for these fluctuations include sloughing of bacteria from the PCR material and/or the tubing used in the pumping system, and introduction of bacteria through the Milli-Q water. However, bacterial enumeration of the Milli$Q$ water showed low bacterial populations.

In some of the PCR experiments, an interference prevented measurement of the dissolved oxygen concentrations using the dissolved oxygen probe. Although aeration in the PCRs was visible, no dissolved oxygen was detected. The probe was recalibrated and demonstrated appropriate calibration responses; however, when replaced in the flowthrough cell, no dissolved oxygen was detected. No interference was encountered in measuring the dissolved oxygen concentrations in the CGA solutions. We suggest that the interference may be due to matrix effects on the dispersion of dissolved oxygen through the membrane of the dissolved oxygen probe. This may be the case because problems were encountered for effluents from the PCRs containing core material with slag and core material with coal tar (Table 1). PCR LS-1 and PCR LS-2 both contained local sand collected near Laramie, wyoming (Table 1); however, the sands were collected at different times. The sand used in PCR LS-2 may have been contaminated, thus causing the possible matrix interference in the effluent from this PCR. 


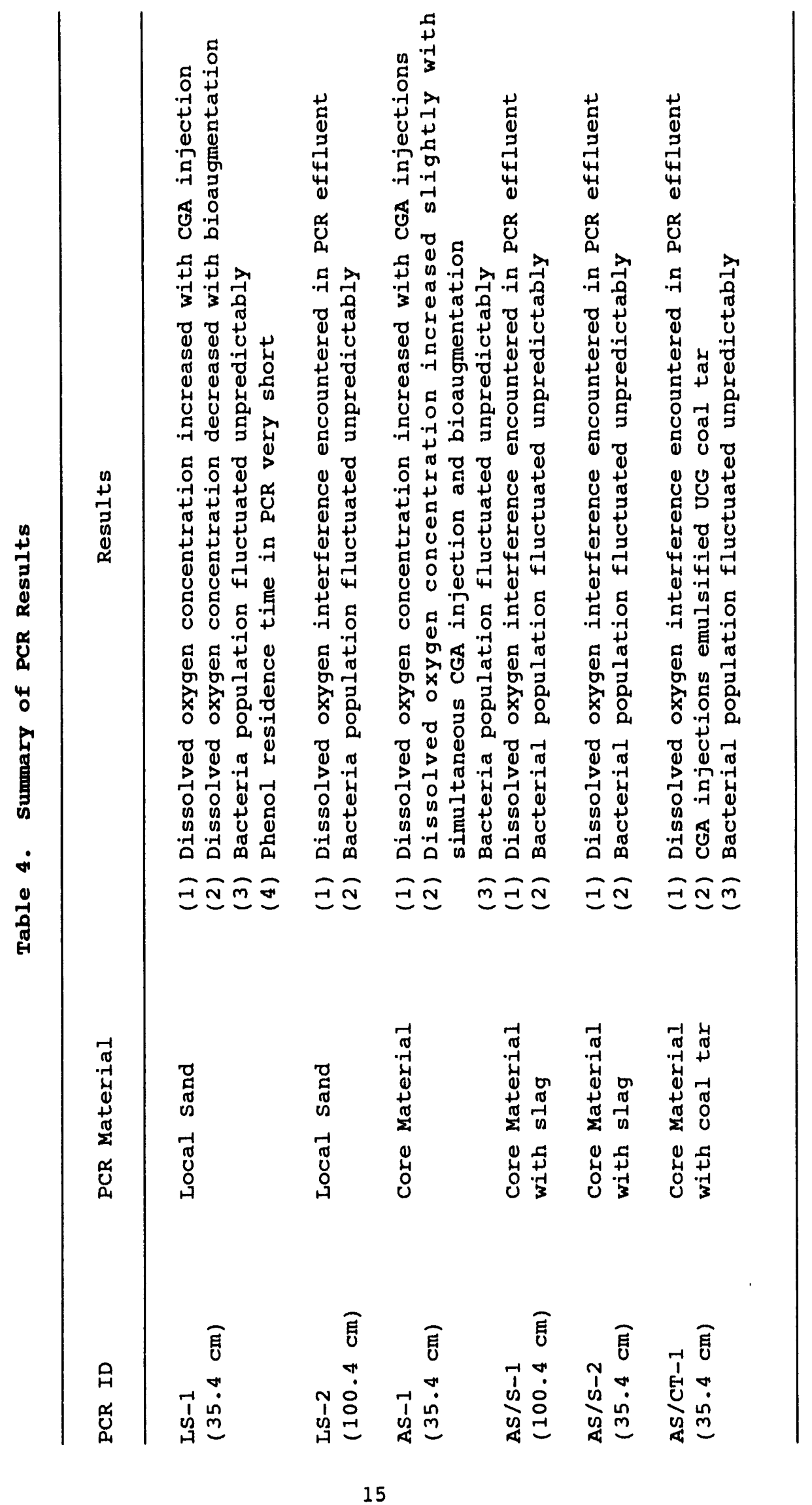


A. CGA solution of $1.0 \mathrm{~mL}$ of surfactant per $1.0 \mathrm{~L}$ of Milli-Q water was injected into PCR LS-1, and the dissolved oxygen concentration of the effluent increased. Figure 4 is a graph of dissolved oxygen concentration versus time and shows the increase in dissolved oxygen concentration as CGAs were injected into the PCR. The dissolved oxygen concentration in the effluent reached $14 \mathrm{mg} / \mathrm{L}$ after the CGA injection. This dissolved oxygen concentration is higher than would be expected. A gas front may have been produced by the colloddal gas aphrons, creating a partial pressure gradient that increased the solubility of oxygen in water and generated a supersaturated solution. Figure 4 also shows a dramatic drop in dissolved oxygen concentration after bioaugmentation.

\section{PCR LS-2}

PCR LS-2, 2.8 times longer than PCR LS-1, was designed to determine the stability and transport of CGAs over distance. $\mathrm{H}_{2} \mathrm{O}_{2}$ injections were also performed as a comparative oxygenation technique. However, the interference mentioned earlier prevented accurate measurement of the dissolved oxygen concentrations in the effluent from this system, and as a result, no information on stability and transport of cGAs over distance or oxygenation by $\mathrm{CGAs}$ and $\mathrm{H}_{2} \mathrm{O}_{2}$ was obtained.

\section{PCR AS-1}

Three CGA injections were made into this PCR. The first CGA solution was prepared using $100 \mathrm{~mL}$ of surfactant per $1.0 \mathrm{~L}$ of $\mathrm{Milli-Q}$ water. The next two CGA solutions were prepared using $50.0 \mathrm{~mL}$ of surfactant per $1.0 \mathrm{I}$ of Milli-Q water.

The first two injections of CGAs produced a substantial increase in the dissolved oxygen concentrations in the PCR effluents (Figure 5). As with PCR LS-1, the dissolved oxygen concentrations in the effluents were higher than expected. Once again, gas fronts in the PCR material, creating partial pressure gradients, may have caused supexsaturated effiuents. The phenol injection, which was made just before the first CGA injection, also contributed to the dissolved oxygen concentration in the effluent. The third CGA injection was made simultaneously with a bioaugmentation, and only a slight increase in dissolved oxygen concentration was observed. This is believed to be due to consumption of the dissolvad oxygen by the bacteria.

For PCR LS-1, the CGA solution prepared using $1.0 \mathrm{~mL}$ of surfactant per $1.0 \mathrm{~L}$ of Milli-Q water had a dissolved oxygen concentration of 8.0 $\mathrm{mg} / \mathrm{L}$ at $11^{\circ} \mathrm{C}$. For PCR AS-1, the CGA solutions prepared using $100 \mathrm{~mL}$ and $50 \mathrm{~mL}$ of surfactant per $1.0 \mathrm{~L}$ of Milli-Q water had dissolved oxygen concentrations of 7.2 and 7.9 at $11^{\circ} \mathrm{C}$, respectively. These results suggest that lower surfactant concentrations result in higher dissolved oxygen concentrations in the CGA solution. 


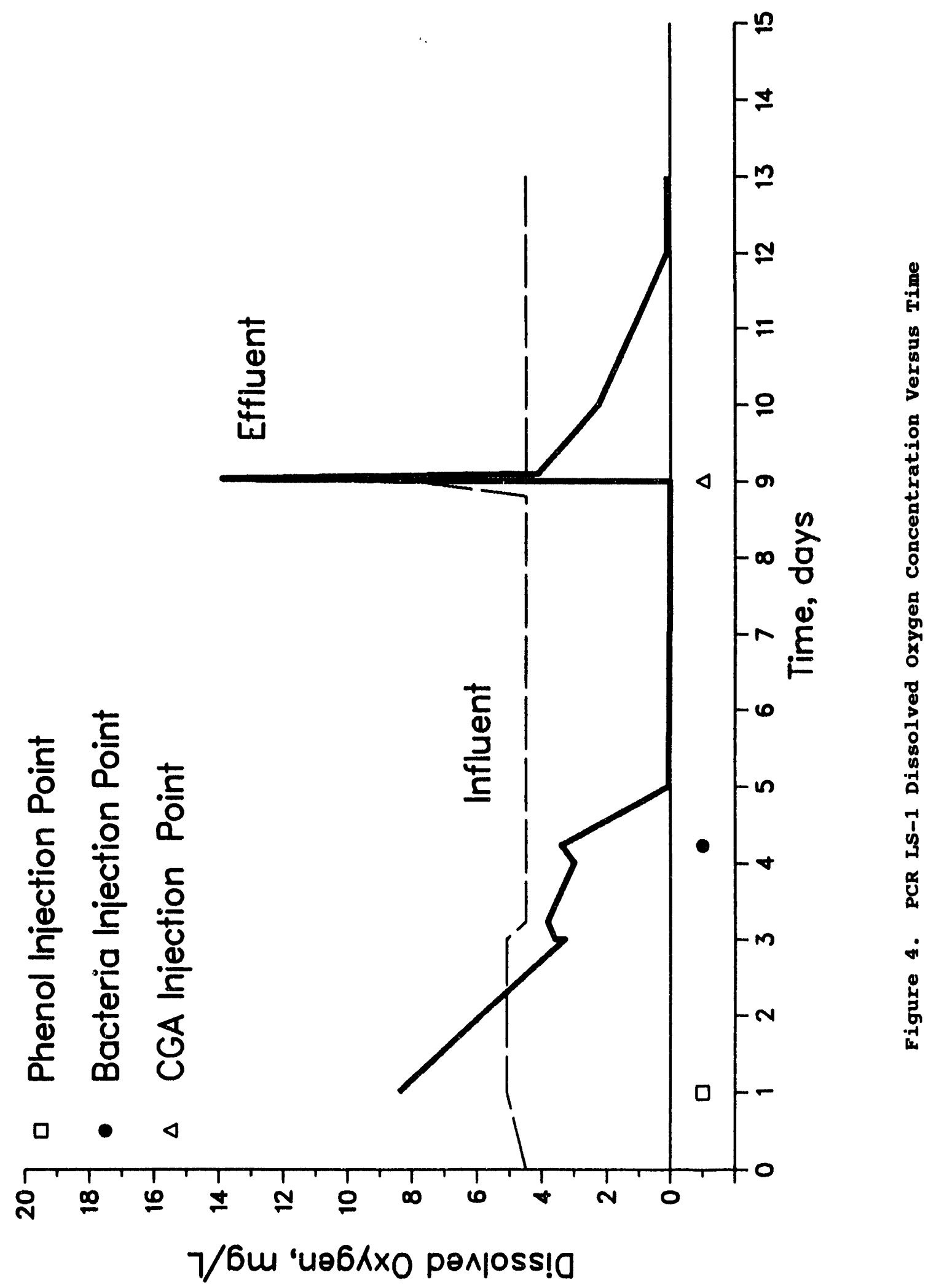




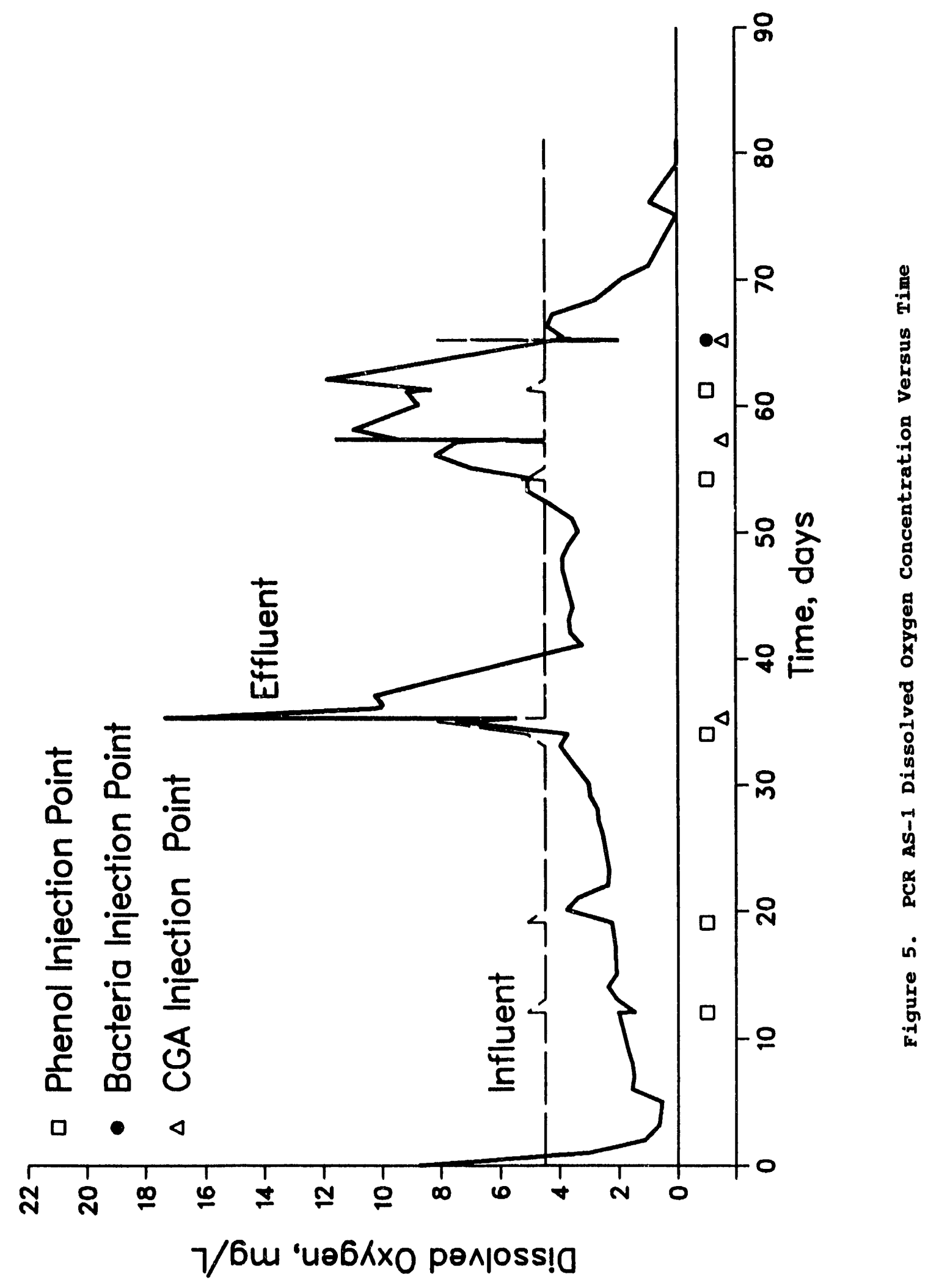


This PCR was designed to evaluate vertical mobility of CGAs and to compare the effects of CGA injection versus $\mathrm{H}_{2} \mathrm{O}_{2}$ injection on the dissolved oxygen concentrations in the effluent. However, the analytical interference in measuring dissolved oxygen concentration was encountered, and as a result, no information was obtained from PCR AS/S-1.

$\underline{\text { PCR AS/S-2 }}$

PCR AS/S-2 was designed to compare the dissolved oxygen concentrations in the effluent after CGA injection and $\mathrm{H}_{2} \mathrm{O}_{2}$ injection. once again, the interference in measuring dissolved oxygen concentrations was encountered, and no accurate data were obtained.

PCR AS/CT-1

PCR AS/CT-1 contained a UCG coal tar mixed with the PCR material. Interference once again prohibited an accurate measurement of the dissolved oxygen concentrations in the PCR AS/CT-1 effluents. However, we did determine that the surfactant in the CGA solutions emulsified and dislodged the coal tar. GC/MS analysis using EPA Method 625 detected high concentrations of organic compounds from the coal tar in the effluent after the introduction of CGAs. Chromatograms of Tergitol and coal tar show the organic compounds detected in both substances (Figures $6 a$ and $6 b)$. Figures $7 a$ and $7 b$ show chromatograms of the effluent before and after the injection of CGAs. Although we did not identify the organic compounds in the effluent, it is easy to establish their origin by comparing the chromatogram of coal tar with the chromatogram of the effluent collected after CGA injection. 

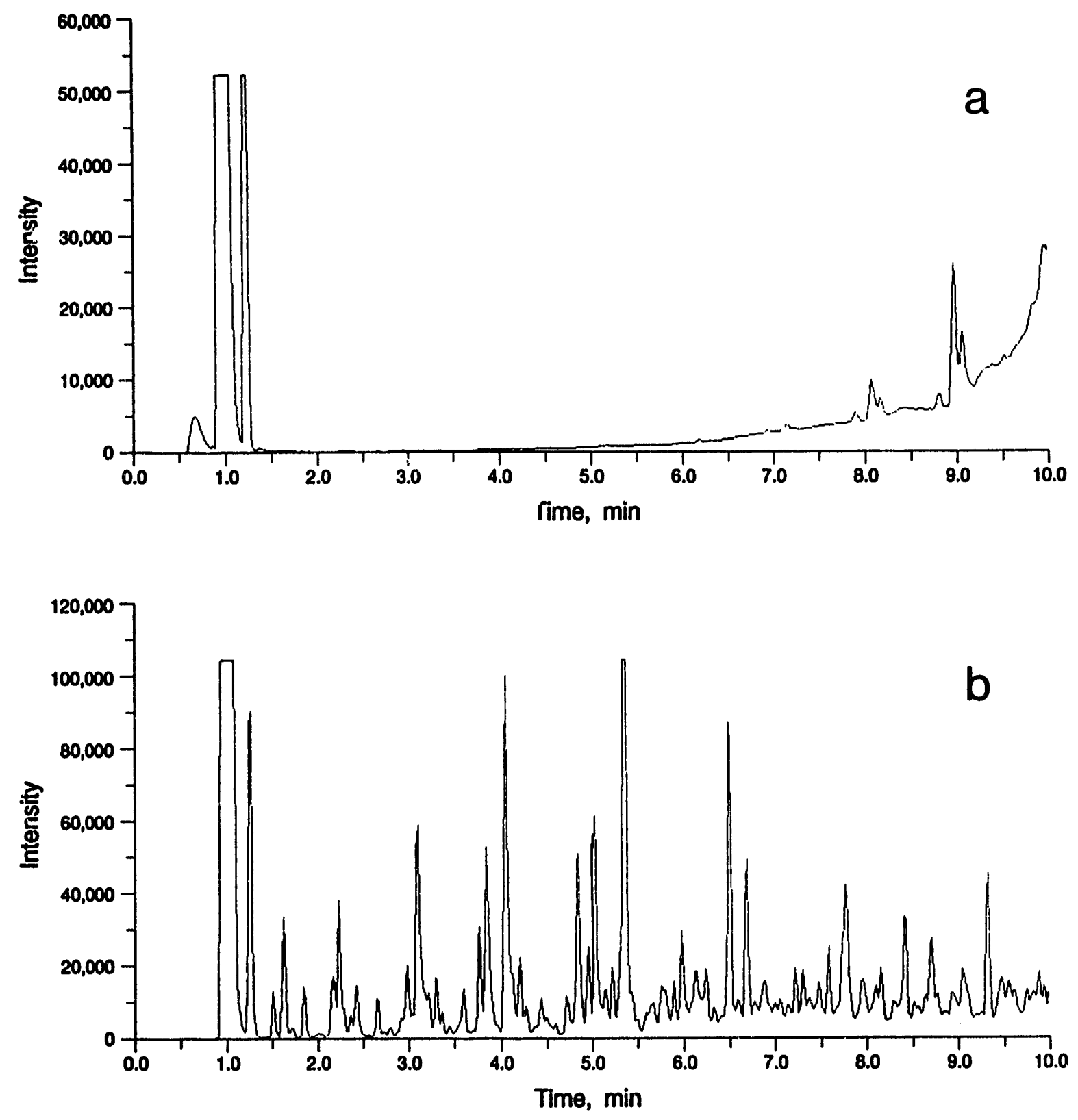

Figure 6. Chromatograms of: (a) Tergitol and (b) UCG Coal Tar 

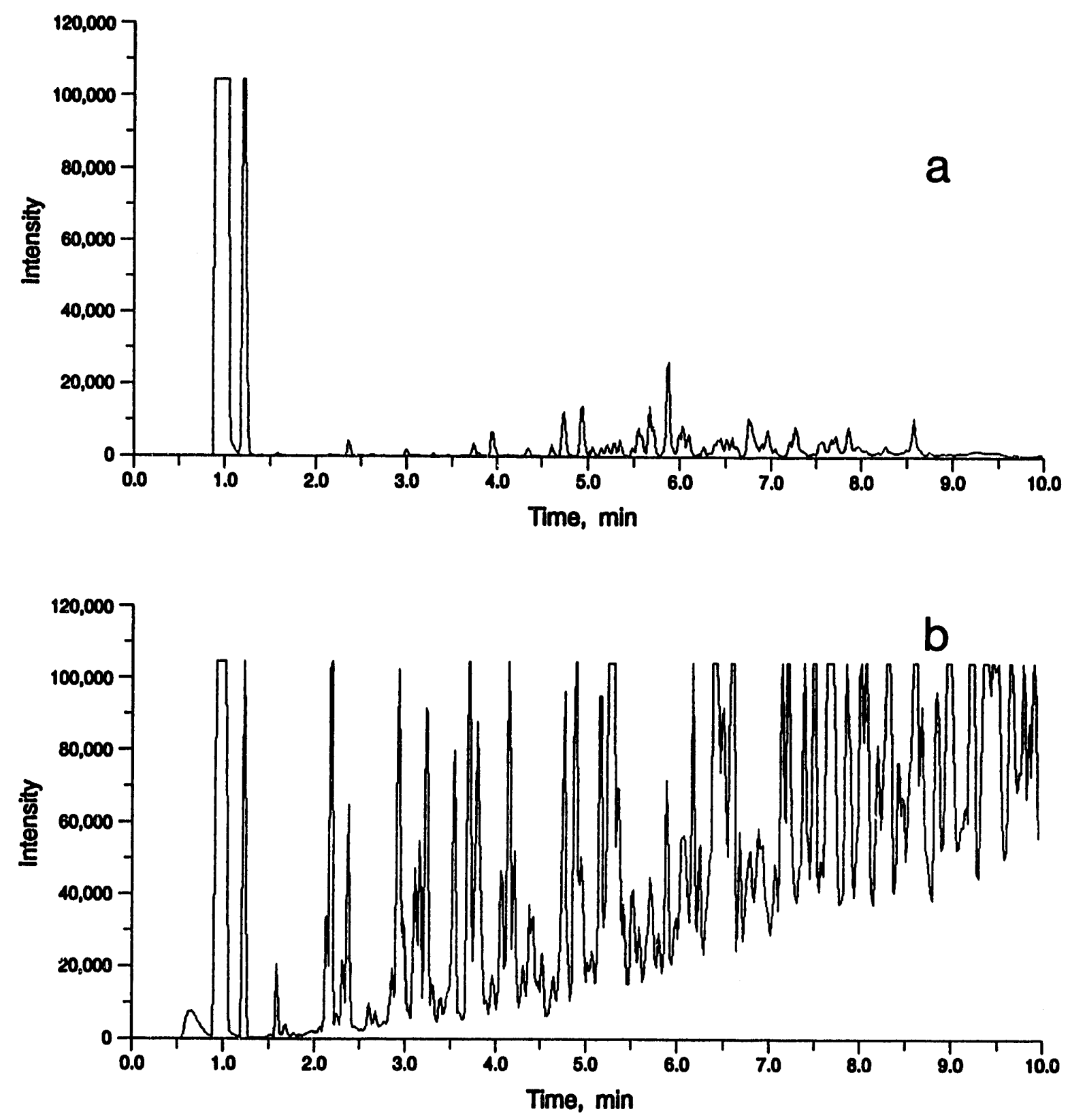

Figure 7. Chromatograms of PCR PS/CT-1 Effluent: (a) Before CGA Injection and (b) After CGA Injection 


\section{CONCLUSIONS}

Generation and transport of CGAs was successfully demonstrated in two of the PCRs, and elimination of the interference in measuring dissolved oxygen concentrations in the effluents from the other PCRs may also have shown this. The interference greatly reduced the amount of data available upon which to base our conclusions; however, our limited findings suggest that oxygen generation through CGA injection is a viable subsurface oxygenation technique.

We were not able to determine if bioaugmentations or $\mathrm{CGA}, \mathrm{H}_{2} \mathrm{O}_{2}$, and phenol injections enhanced bacterial growth because of the unpredictable fluctuations of the bacterial populations in our control systems; however, we did show that the bacteria isolated from the UCG site can degrade phenol. This, along with our findings concerning CGA injection and oxygenation, leads us to conclude that enhanced bioremediation of subsurface environments is feasible. However, there are problems (such as the unpredictable fluctuations in bacterial populations and analytical difficulties) associated with studying this in situ technology that must be addressed. In addition, much more information concerning the many mechanisms interacting simultaneously in this technology is needed.

Based on the results from our research, we can also conclude that CGAs act as a soil-washing agent. This may be of significance for freeing organic matter and making it more accessible to bacteria for degradation, and also shows a possible separate application of CGAs as a soil-washing agent.

\section{RECOMMENDATIONS}

Based on the results from this research, the following recommendations are made:

- The interference that prevented accurate dissolved oxygen concentration measurements should be investigated, and other methods for measuring dissolved oxygen should be evaluated.

- Methods should be developed to stabilize bacterial populations prior to introducing variables into the PCR systems.

- The effect of the CGA surfactant on bacterial populations should be evaluated.

- studies on the effect of the surfactant concentration in the CGA solution on the dissolved oxygen concentration in the CGAs should be performed. 
- After the items listed above are addressed and resolved, further research is needed to evaluate the use of CGAs as a subsurface oxygenation technique, specifically the ability of cGAs to enhance biodegradation rates via their effect on bacterial populations. Surfactant-to-water ratios, transport of CGAs over distance, and use of a contaminated material in the PCR system should be studied.

- Further evaluations of the use of CGAs as a washing agent to free organic compounds from solid matrices should be performed. 


\section{ACKNOWLEDGMENT}

The authors express thanks to the U.S. Department of Energy for funding of this research under Cooperative Agreement DE-FC21-86MC11076.

\section{DISCLAIMER}

Mention of specific brand names or models of equipment is for information only and does not imply endorsement of any particular brand. 


\section{REFERENCES}

Adams, J.C., 1986, Phenol Degradation by Indigenous Bacteria in UCG Wastewater. Laramie, WY, WRI unpublished Research Report to DOE.

Dalton, V.A., and J.H. Campbell, 1978, Laboratory Measurements of Groundwater Leaching and Transport of Pollutants Produced During Underground Coal Gasification. In Situ 2: 295-328.

Ethridge, F.G., L.K. Burns, W.G. Alexander, G.N. Craig II, and A.D Youngberg, 1979, overburden Characterization and Post-Burn study of the Hoe creek Wyoming Underground coal Gasification site and Comparison with the Hanna, wyoming site. Colorado state University and Laramie Energy Technology Center DOE/LC/10705-T1.

Foss R.A., 1989, Microbubble Injection as an Aeration Technique for InSitu bioremediation. Summer National Meeting American Institute of Chemical Engineers, Philadelphia, PA.

Freeze R.A., and J.A. Cherry, 1979, Groundwater. Prentice Hall, Englewood Cliffs, NJ.

Horvath, S.R., 1972, Microbial Co-Metabolism and the Degradation of organic Compounds in Nature. Bacteriological Reviews, 36: 146-155.

Hwang, M.-H., R.E. Hodson, and D.L. Lewis, 1989, Assessing Interactions of Organic Compounds During Biodegradation of Complex Waste Mixtures by Naturally occurring Bacterial Assemblages. Environmental Toxicology and Chemistry, 8: 209-214.

Kim, C.J., and W.J. Maier, 1987, Biodegradation of Pentachlorophenol in Soil Environments. 41 st Purdue University Industrial Hazardous Waste Proceedings, West Lafeyette, IN, p. 303-312.

Longe, T.A., 1989, Colloidal Gas Aphrons: Generation, Flow Characterization and Application in soil and Groundwater Decontamination. Doctoral Dissertation, Chemical Engineering, Virginia Polytechnic Institute and State University, Blacksburg, VA.

Mead, S.W., F.T. Wang, D.H. Stuermer, E. Raber, H.C. Ganow, and R. stone, 1980, Implications of Ground-Water Measurements at the Hoe creek UCG Site in Northeastern wyoming. Proceedings of the 6 th Annual Underground Coal Conversion Symposium, Shangra-La, OK, UCRL84083.

Michelsen, D.L., D. Wallis, and S. Lavinder, 1985, In-situ Biodegradation of Dispersed Organic Using a Microdispersion of Air in Water. Proceedings of the $6 \mathrm{th}$ National Conference on Management of Uncontrolled Hazardous Waste sites, Washington, DC. 
Michelsen, D.I., T.A. Longe, J.W. Smith and J.A. Suggs, 1988 . A Microbubble Dispersion in Water - What Role in Industrial Waste Treatment? Proceedings of the 20th Mid-Atlantic Industrial Wastewater and Hazardous Materials Conference, Howard University, Washington, DC.

Michelsen, D.L., W. Foreman, and D. Michelsen 1988b. Large Scale Generation of Microbubbles to Improve Flotation Processes and to Save Energy. Separations Innovative concepts Fair, U.S. DOE (Pacific Northwest Laboratory), p. 9.1-9.19.

Michelsen, D.L., J.W. Smith and J.A. Suggs, 1988C. Use of Colloidal Gas Aphrons for In-situ Biodegradation of Contaminated Groundwater. Proceedings of the 14th Annual Hazardous Waste Symposium, U.S. EPA, Cincinnati, $\mathrm{OH}$.

Nolan, B.T., and S. Suthersan, 1987, Laboratory studies on Evaluation of In situ Biodegradation at the Hoe creek underground coal Gasification Site. DOE/MC/11076-2683.

Rickabaugh J., S. Clement, and R.F. Lewis, 1987, surfactant Scrubbing of Hazardous Chemicals From soil. 41 st purdue University Industrial Waste Conference Proceedings, West Lafayette, IN, p. 377-382.

Sebba, F., 1985, An Improved Generator for Micron-Sized Bubbles. Chemistry and Industry, Vol. 91.

Smith J.W., 1988, The Development of Methods and Equipment for the study of the Aerating Capabilities of a Microdispersion of Air in Water. Masters Thesis, Chemical Engineering, Virginia Polytechnic Institute and State University, Blacksburg, VA.

Standard Heterotrophic spread Plate Count Method 907-B, 1985. Standard Methods for the Examination of Water and Waste Water, American Water Works Association, Denver, CO, 16th Edition, p. 860-864.

Stuermer, D.H., D.J. Ng, C.J. Morris, 1982, organic contaminants in Groundwater near an Underground coal Gasification site in Northeastern Wyoming. Environmental sciences and Technology, 16 (9): 582-587.

U.S. EPA, 1984a, Method 604, Phenols. Federal Register, October 26, 1984 , Vol. 49 , No. 209.

U.S. EPA, 1984b, Method 625, Base/Neutrals and Acids. Federal Register, October 26,1984 , Vol. 49 , No. 209 .

Wang F., and W. Mead, 1985, Changes in Major organic Contaminants in the Groundwater at the Hoe Creek Underground Coal Gasification site. Proceeding of the 11 th Annual Underground coal Gasification Symposium, Denver, CO, UCRL-93227. 


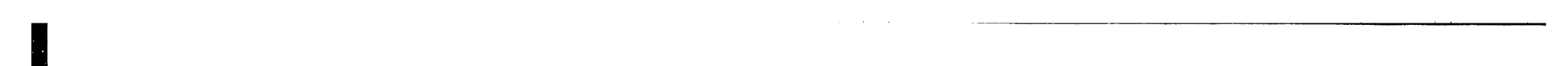

